\title{
ANALISIS ORGANISASI PEMERINTAH DAERAH KHUSUS IBUKOTA JAKARTA SEBAGAI SEBUAH SISTEM TERBUKA
}

\author{
Heru Nurasa
}

\author{
Ketua Jurusan Ilmu Administrasi Negara FISIP UNPAD \\ Email:heru.nurasa@unpad.ac.id
}

\begin{abstract}
ABSTRAK. Studi ini mengambil objek Pemerintah Daerah Khusus Ibukota Jakarta, serta dikaji dengan menggunakan pendekatan organisasi sebagai sistem terbuka. Pendekatan ini digunakan untuk memahami lingkungan organisasi, baik lingkungan internal dan eksternal, sebagai bahan informasi bagi penyusunan kebijakan (rencana stratejik) ke depan. Studi ini menggunakan metode deskriptif, untuk mengungkap secara objektif berbagai tantangan yang dihadapi Pemda DKI, dalam posisinya sebagai ibukota dapat diidentifikasi dari lingkungan internal (skala lokal) dan lingkungan eksternal (skala nasional/internasional). Hasil studi menunjukan bahwa pada skala lokal persoalan kependudukan, ketenagakerjaan, kemiskinan, transportasi/ perparkiran, dan lingkungan hidup merupakan masalah inti yang memerlukan penanganan secara tepat dan cepat. Sementara itu, pada skala nasional/internasional, persoalan liberalisasi perdagangan merupakan masalah paling krusial. Skenario Pemda DKI Jakarta untuk menangani tantangan yang dihadapi dengan menggunakan kebijakan REGOM (reinventing government manajemen), yaitu dengan melakukan perubahan dan pembaharuan sistem manajemen pemerintahan. Kebijakan khusus yang dibangun adalah dengan melakukan reformasi anggaran, reformasi organisasi, dan kebijakan privatisasi dan kemitraan dengan dunia usaha (swasta) dan masyarakat.

Kata kunci: Organisasi sebagai sistem terbuka, reinventing government, good governance.
\end{abstract}

\section{ORGANIZATIONAL ANAL YSIS OF SPECIAL CAPITAL REGION OF JAKARTA AS OPEN SYSTEM}

ABSTRACT. The object of this study is Jakarta capital city which was studied by the organization theory as open system. This approach was using to have an understanding of organizational environment, those are internal and also external environment, as an informations based to formulating the future policy (or strategic plan) of Jakarta capital city. Descriptive methode was used in this study to explored objectively the opportunities and threats from internal environment (local scale) and external environment (national and international scale) faced by Jakarta capital city as a central city of Indonesia. The result of study showed that the problems of Jakarta capital city at local level are related with the isues of demography, manpower, poverty, transportation, and environment which are needed to solved accurately. Meanwhile, the liberalization of trading become the crusial problem at national and international level. The scenario policy of Jakarta capital city, to handled the problems from internal and external environment, was promoting reinventing government management policy, in order to reinvent the government management systems, including budgeting reform, organizational revitalization, and privatization and partnership policy between local government and private sector and civil society.

Key word: Organizations as open system, reinventing government, good governance.

\section{PENDAHULUAN}

Analisis organisasi sebagai sistem terbuka juga sangat relevan digunakan pada organisasi manapun, utamanya birokrasi pemerintahan. Dewasa ini, pengaruh perubahan lingkungan - baik skala lokal, nasional, maupun internasional merupakan faktor terpenting yang harus diperhatikan serta diperhitungkan secara matang dalam rangka merumuskan kebijakan (baca: strategi) pemerintah. Krisis ekonomi yang berkepanjangan, berawal pada pertengahan tahun 1998, merupakan bukti bahwa kebijakan pemerintah Indonesia kurang mampu merespons tuntutan perubahan lingkungan. Kondisi moneter dan sektor riil menjadi sedemikian terpuruk, pajak 
pun sulit untuk ditarik. Sementara pinjaman luar negeri pun persyaratannya semakin sulit. Pemerintah Indonesia mengalami kesulitan untuk memperoleh dana dalam rangka membiayai penyelenggaraan pemerintahan dan pembangunannya. Terjadi defisit anggaran pemerintah. Bahkan pada masa itu muncul rumor bahwa untuk membayar gaji pegawai negeri sipil, polisi dan militer diperkirakan tidak mampu untuk membayarnya.

Ketergantungan pemerintah Indonesia terhadap pinjaman luar negeri merupakan bukti bahwa lingkungan moneter internasional bagitu kuat mempengaruhi kebijakan birokrasi pemerintah. Bahkan untuk memperoleh dana pinjaman luar negeri, lembaga keuangan internasional menerapkan persyaratan berat, seperti: penciptaan iklim demokrasi, penegakan HAM, pemberantasan korupsi, dst. Hal ini juga seringkali dipandang sebagai ikut campur urusan dalam negeri Indonesia. Tetapi jika persyaratan tersebut tidak diikuti, maka pinjaman luar negeri pun tidak akan dikucurkan. Jadi jelaslah bahwa birokrasi pemerintah tidak mungkin menjalankan organisasinya dengan pendekatan organisasi tertutup semata. Faktor lingkungan eksternal berupa IPOLEKSOSBUD, baik pada tingkat lokal, nasional dan internasional harus diadaptasi ke dalam kebijakan birokrasi pemerintah.

Intinya, strategi adaptasi organisasi terhadap perubahan lingkungan eksternal merupakan keniscayaan. Pendekatan organisasi sistem terbuka merupakan paradigma terkini yang wajib diterapkan, baik pada organisasi perusahaan, birokrasi pemerintahan, dan bahkan pada organisasi sosial sekalipun. ${ }^{1} \quad$ Manajemen stratejik pun,

\footnotetext{
1 Menurut pendekatan organisasi sistem terbuka, bahwa organisasi tidak beroperasi dalam situasi eksklusif (tertutup). Tetapi dia beroperasi dalam sistem lingkungan yang lebih besar, yang saling mempegaruhi satu sama lain. Dengan demikian, organisasi bagaikan sub-sistem dari sistem lingkungan yang lebih besar. Artinya, setiap perubahan pada sistem lingkungan organisasi, maka baik langsung maupun tidak langsung akan mempengaruhi keberadaan dan pertumbuhan organisasi tersebut. Ketergantungan organisasi terhadap lingkungannya terjadi dalam 2 (dua) bentuk keterkaitan, yaitu; keterkaitan ke belakang (backward linkages) dan keterkaitan ke depan (forward linkages). Kekerkaitan ke bekalang dalam upaya mengakses sumberdaya (dana, bahan baku, tenaga kerja, teknologi, dsb), sementara keterkaitan ke depan dalam upaya mengakses ke pasar (konsumen atau publik).
}

utamanya pada fase perencanaan stratejik, hanya dapat diterapkan jika mengasumsikan organisasi sebagai sistem terbuka. Analisis SWOT, khususnya analisis tentang opportunity (peluang) dan threat (ancaman), adalah analisis terhadap peluang dan ancaman dari lingkungan eksternal organisasi, agar organisasi senantiasa dapat merespons dan melakukan antisipasi strategis secara cepat dan tepat.

Dengan argumentasi di atas, maka kajian terhadap Pemda DKI sebagai organisasi briokrasi yang sangat signifikan untuk dikaji dengan pendekatan organisasi sebagai sistem terbuka. Hal ini mengingat Pemda DKI sebagai pintu gerbang Indonesia dalam berinterakasi dengan dunia internasional, serta dituntut menjadi centre of excelence bagi Daerah-Daerah (Propinsi, Kabupaten, dan Kota) di Indonesia.

\section{Teori Organisasi sebagai Sistem Terbuka}

Kajian tentang organisasi sebagai suatu pendekatan terbuka, pada prinsipnya adalah mengkaji proses adaptasi organisasi terhadap lingkungannya. Proses adaptasi ini dilakukan mulai dari hulu (backward linkages) sampai ke hilir (foreward likages), yaitu mulai dari lingkungan input dalam upaya untuk memperoleh sumberdaya (resourcess) yang diperlukan, sampai kepada lingkungan output untuk menawarkan segala macam produk yang dihasilkannya. Dengan demikian, bagi suatu organisasi, bahwa kegiatan adaptasi terhadap lingkungannya merupakan suatu keniscayaan, yaitu dengan melakukan tindakantindakan strategis agar organisasi dapat melakukan suatu transaksi timbal balik yang saling menguntungkan dengan lingkungannya. Pendekatan organisasi sistem terbuka, kemudian menjadi era baru dalam kajian teori organisasi. Joan Woodward $(1965)^{2}$, meneliti pengaruh lingkungan teknologi terhadap struktur organisasi. Penelitian serupa dilanjutkan oleh para peneliti lainnya, diantaranya Charles Perrow $(1967)^{3}$ dan James Thompson $(1967)^{4}$. Burns dan Stalker

\footnotetext{
2 Joan Woodward, Indusstrial Organization: Theory and Practice, London: Oxford University Press, 1965.

${ }^{3}$ Charles Perrow, "A Framework for the Comparative Analysis of Organizations," American Sociological Review, April 1967, pg 194-208.

4 James D. Thompson, Organization in Action, New York; Mc Graw Hill, 1967.
} 
$(1961)^{5}$ serta Lorch and Lawrence $(1967)^{6}$ juga memberikan gambaran bahwa struktur yang dianut oleh organisasi dipengaruhi oleh lingkungannya. Karena itu setiap lingkungan yang berbeda tidak bisa dihadapi oleh struktur yang sama.

Konsep "adaptasi" itu sendiri sesungguhnya diadopasi dari ilmu alam, utamanya ilmu biologi, yang menjelaskan reaksi dari suatu organisme untuk dapat bertahan terhadap tuntutan dan tekanan perubahan lingkungannya (mekanisme survival strategy). Dengan demikian, pengertian adaptasi dapat dijelaskan sebagai suatu tindakan organisme untuk melakukan perubahan struktur dalam rangka memelihara keadaan setimbang terhadap perubahan lingkungan yang dinamis, sehingga akan membentuk suatu komposisi struktur lingkungannya yang saling bersinergis. ${ }^{7}$ Cyert dan March $^{8}$ mengemukakan bahwa keadaan setimbang ini tidaklah statis, tetapi akan terus mengalami perubahan menuju keadaan kesitimbangan yang baru, sebagai bentuk respons terhadap adanya perubahan tujuan organisasi, serta tuntutan dan tekanan perubahan lingkungan yang bergerak dinamis. Sementara itu, para ahli organisasi yang menganut pendekatan kontingensi mengemukakan bahwa keadaan setimbang tersebut akan dipertahankan melalui penerapan struktur organik atau struktur mekanik. ${ }^{9}$ Struktur organik digunakan pada lingkungan yang cepat berubah (turbulent), karenanya struktur organik sifatnya lebih fleksibel dan tidak formal. Namun, sebaliknya pada lingkungan yang relatif stabil akan menggunakan struktur mekanik (umumnya bersifat kaku dan formal), karenanya struktur mekanik dapat menjamin adanya kepastian (certainty) dan keseragaman (uniformity). Pandangan ini dalam pemikiran Astley Van de Ven, menganut suatu asumsi tentang orientasi pelaku yang bersifat

\footnotetext{
5 Tom Burns and G.M. Stalker, The Management of Innovation, Tavistock, 1961, pg 25.

6 Paul R. Lawrence and Jay W. Lorsch, Organization and Environment, Boston Graduate School of Business Administration, Harvard University 1967, pg 25-30.

${ }^{7}$ Roy A Rapaport, Ritual, Sanctity, and Cybernetics, American Anthropologist, Vol 73, (1971).

${ }^{8}$ Richard M. Cyert and James G. March, A Behavioral Theory of the Firms (Englewood Cliffs, N.J. Prentice Hall, 1963.

9 Tom Burn dan G.M. Stalker, The Managament of Innovation, Tavistock, 1961.
}

diterministik ${ }^{10}$, serta perspektif tindakan rasional ${ }^{11}$. Selanjutnya Astley Van de Ven mengemukakan bahwa terdapat tiga aspek utama yang perlu diperhatikan untuk menjelaskan proses adaptasi organisasi berlangsung, yaitu: (1) aspek struktur, (1) aspek tuntutan perubahan, serta (3) aspek perilaku dan peran manajer. Aspek struktur merupakan gambaran tentang rancangan posisi dan peran yang melahirkan hirarkhi dan fungsi organisasi, sehingga organisasi dapat dibentuk untuk melaksanakan tugas pokok dan fungsi nya secara efektif dan efesien. Kemudian, perubahan struktur seperti downseizing, rightseizing, dan bahkan upseizing akan dilakukan sebagai bentuk respons organisasi terhadap tuntutan perubahan lingkungan. Sementara itu, perilaku adaptasi pun (seperti perubahan struktur), akan ditentukan oleh peran dan perilaku aktor. Pemikiran ini pada dasarnya menampakan sifat reaktif dari para aktor organisasi (pengambil keputusan) dalam merespons tuntutan perubahan lingkungannya.

Sementara itu, para ahli organisasi lainnya yang menganut analisis populasi mengemukakan bahwa proses perubahan organisasi berlangsung melalui mekanisme seleksi. Pemikiran ini lahir, antara lain ditandai oleh adanya kritikan dari Hannan dan Freeman terhadap model adaptasi dalam merespons perubahan. Menurutnya terdapat kendala, baik dari dalam ataupun luar organisasi, yang menyebabkan keterbatasan adaptasi organisasi terhadap lingkungan yang dinamis. Kendala organsasi dari dalam adalah dapat berupa struktur (inertia struktural) dan atau politik internal yang cenderung resisten terhadap perubahan. Sementara itu kendala dari luar organsasi dikarenakan adanya ketergantungan terhadap sumberdaya yang terbatas (resource dependency). Dalam perspektif ekologi, bahwa keterbatasan sumberdaya itu disebabkan oleh daya pikul (carrying capacity) lingkungan yang juga terbatas. Oleh karena itu, perubahan organisasi sesungguhnya lebih tepat jika dijelaskan melalui

10 W. Graham Astley and Andrew Van de Ven, Central perspectives and Debates in Organization Theory, Administrative Science Querterly, 28, 1983, pg 248-250.

11 Jeffrey Pfeffer, Organizations and Organization Theory, London, Pitman Publishing Inc, 1982. 
mekanisme seleksi alamiah dari lingkungannya. ${ }^{12}$ Dalam pemikiran ini perubahan dijelaskan melalui 3 (tiga) tahapan proses perubahan : (a) Pertama, terdapat perbedaan keragaman bentuk organisasi yang disebabkan oleh hal-hal yang bersifat lokal (seperti visi, misi, tujuan organisasi). Perbedaan keragaman (variasi) bentuk ini, kemudian, menyebar ke seluruh populasi melalui prosess dufusi. (b) Selanjutnya, keragaman itu terbentuk melalui suatu proses alamiah, dimana lingkungan akan memilih bentuk yang paling ideal (saling bersinergis). Kemudian, keragaman bentuk yang sesuai dengan basis resources lingkungan lah yang akan dipertahankan. Sementara ragam bentuk yang tidak cocok akan hilang (tidak survive). (c) Akhirnya,variasi bentuk yang ideal inilah yang akan bertahan. Proses mempertahankan ragam bentuk ideal ini dilakukan melalui pembentukan komitmen bersama. Pada intinya, bahwa analisis populasi melihat proses perubahan atau daur hidup organisasi berlangsung dalam suatu siklus ragam (variasi) bentuk-seleksi - dan retensi (bertahan). Dengan demikian, dalam pemikiran seleksi alamiah bahwa proses perubahan dijelaskan dari kesesuaian organisasi terhadap sumberdaya lingkungannya (resource depence), berbeda dengan pemikiran model adaptasi atau strategi yang lebih melihat perubahan tersebut dari sudut penataan internal organisasi semata. Organisasi yang lolos dari seleksi alamiah, adalah organisasi yang mampu menyesuaikan (fitting) dirinya dengan sumberdaya lingkungannya.

Kritikan terhadap pendekatan teori adaptasi ataupun populasi organisasi, melihat hubungan organisasi dengan lingkungan berlangsung secara otomatis (pendekatan imperative). Padahal hubungan-hubungan tersebut tidaklah berlangsung secara mekanistik, artinya perubahan struktur, proses dan perilaku organisasi tidaklah secara otomatis melakukan penyesuaian-penyesuaian atas kondisi dan tekanan perubahan lingkungan tersebut. Perubahan tersebut terjadi melalui persepsi dan intervensi aktor dalam menilai dan memilih tujuan organisasi. Berger dan Luckman, menolak pendapat bahwa organisasi merupakan sistem yang impersonal (deterministik dan rasional),

\footnotetext{
12 Michael T. Hannan and John H. Freeman, The Population Ecology of Organization, American Journal of Sociology,vol 82, p 929-964.
}

yaitu terlepas dari persepsi dan intervensi aktoraktor di dalam organisasi. Kondisi dan keberadaan organisasi justru dibentuk, dipertahankan dan di rubah berdasarkan persepsi para aktor berdasarkan pemahamannya kepada situasi lingkungannya (enacted environment). Perspesi aktor organisasi inilah yang justru menggerakan perilaku organisasi $^{13}$.

Dalam pandangan ini bahwa hubungan organisasi dengan lingkungan dijelaskan melalui konsep enactment (Gerloff, 1985). Menurut Gerloff, hubungan antara organisasi dengan lingkungan berlangsung melalui penetapan operasi kegiatan (enacted domain), baik melalui proses perhatian selekstif maupun melalui pilihan bidang kegiatan. Untuk itu, dalam memahani penyesuaian organisasi terhadap lingkungannya dimediasi oleh persepsi pelaku. Pandangan enactment, dikonstruksikan Gerloff (1985) dalam Gambar 1.

Sejalan dengan pemikiran Gerloff, kemudian Weick dengan menawarkan model enactment selection - retention. ${ }^{14}$ Melalui proses "enactment", aktor organisasi lah yang melakukan penataan organisasi dalam rangka mengeliminasi atau bahkan menghilangkan kendala lingkungannya. Artinya, mekanisme seleksi tidak berlangsung secara alamiah karena tekanan lingkungannya, akan tetapi melalui strategi yang ditetapkan berdasarkan persepsi aktor terhadap perubahan lingkungannya. Sementara itu, proses retensi pun tidak berlangsung secara otomatis berdasarkan kesesuainnya dengan lingkungan, tetapi berdasarkan pengalaman dan pengetahuan para aktor, dimana proses ini terus berlangsung secara berkesinambungan. Dengan pikiran ini, pengaruh lingkungan akan dimaknai dan disikapi secara "berbeda", tergantung pada strategi yang dirumuskan oleh (aktor-aktor) organisasi. Intinya, bahwa bukan lingkungan yang membentuk organisasi, tetapi justru lingkungan itu sendiri dapat dirubah melalui tindakan kolektif.

\footnotetext{
${ }^{13}$ Peter Berger and Thomas Luckman, The Social Construction of Reality, England, Penguin Books Ltd, 1981.

${ }^{14}$ Karl E. Weick, The Social Psychology of Organizing, Reading, Addison Wesley, 1976.
} 


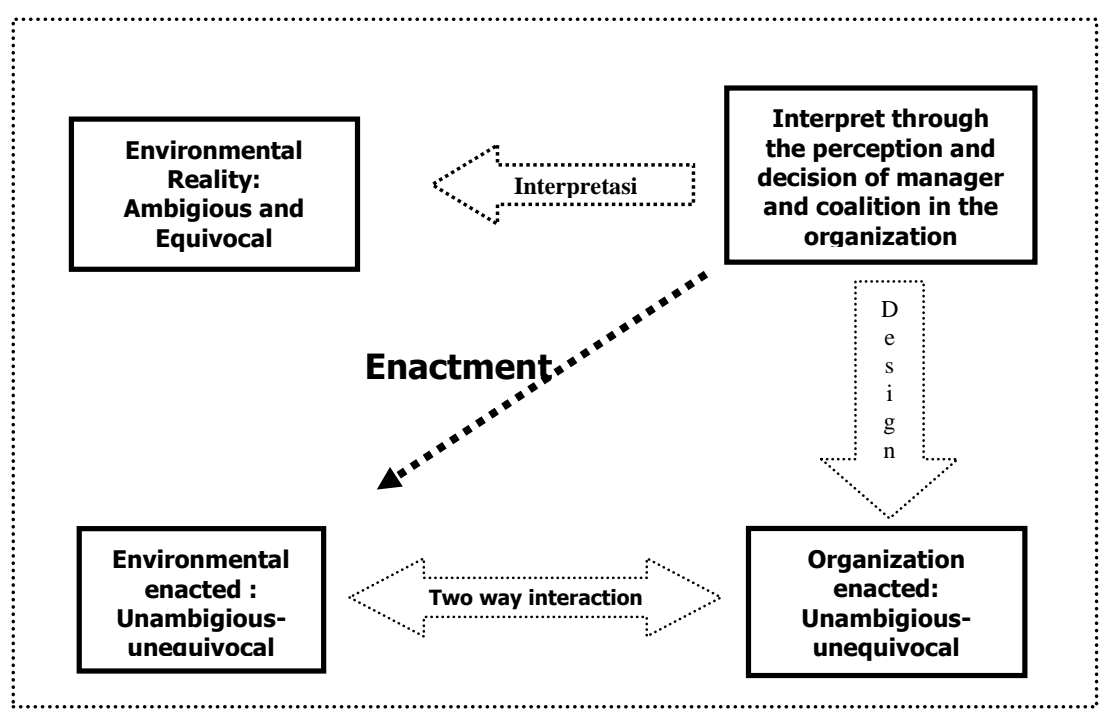

Gambar 1. persepsi pelaku. Pandangan enactment, Sumber: Gerloff (1985)

\section{METODE}

Studi ini memfokuskan kajiannya pada analisis organisasi sebagai sistem terbuka, utamanya birokrasi pemerintahan pada Pemda DKI Jakarta. Dalam penelitian ini tentunya tidak sekedar menjelaskan apa dan bagaimana proses adaptasi tersebut berlangsung. Tetapi lebih jauh lagi mencari tahu mengapa proses adaptasi itu berlangsung kearah konstruksi model seperti sekarang. Analisis dititikberatkan pada interkasi organisasi dengan lingkungan strategis disekitarnya, yang secara terus menerus mengkonstruksikan, mempertahankan, dan merubah struktur dan sistem organisasi, sebagai tindakan strategis di dalam mengantisipasi pengaruh lingkungan eksternal. Untuk itu, kajian ini menggunakan metode deskriptif, dengan meneliti berbagai dokumen serta melakukan observasi dan wawancara dengan informan kunci untuk memperoleh informasi tentang apa, bagaimana, dan mengapa proses adaptasi organisasi Pemda DKI mengarah kepada konstruksi model struktur dan sistem yang ada pada saat ini.

\section{Gambaran Lingkungan Strategis DKI Jakarta}

Dalam statusnya sebagai ibukota Negara Republik Indonesia, Jakarta diposisikan sebagai pintu gerbang Indonesia dalam berinteraksi dengan dunia luar. Image tentang Indonesia pun dapat dikenali pertama kali oleh dunia internasional, melalui wajah DKI Jakarta. Sementara ke dalam sendiri, khususnya bagi Daerah lainnya di Indonesia, DKI Jakarta diposisikan sebagai center of exelence bagi perkembangan perekonomian, kebudayaan, politik, dsb. Dengan demikian, Pemda DKI Jakarta mempunyai tugas yang cukup berat untuk melakukan positioning dalam manajemen pemerintahannya, baik ke dalam maupun ke luar.

Sementara itu, bagi masyarakat yang bermukin di Daerah, Jakarta seringkali dipandang sebagai kota harapan, walaupun secara bersamaan juga menampakan wajahnya sebagai kota yang penuh dengan berbagai permasalahan. Peningkatan populasi penduduk (khususnya karena arus urbanisasi); kenaikan harga berbagai komoditas yang terus melonjak, khususnya harga tanah karena ketersediaan lahan yang terbatas; masalah lalu lintas, utamanya kemacetan, dengan berbagai dampak lainnya yang timbul; tingginya angka pengaguran dan kriminalitas, merupakan gambaran wajah Jakarta saat ini yang tentunya menuntut kebijakan yang cepat dan tepat untuk penanganannya. Di lain pihak, Jakarta nenampakan wajah yang megah, yaitu dengan terkonsentrasinya pusat kegiatan pemerintahan 
tingkat Pusat (Departemen/Lembaga Non Departemen), berbagai kegiatan bisnis dari perusahaan swasta besar dan PMA, serta juga sebagai pusat investasi bagi Negara Republik Indonesia. Dengan kondisi/keadaan seperti itu, Pemda DKI Jakarta telah menempatkan dirinya sebagai KOTA JASA (SERVICE CITY), sebagai strategi untuk merespons dan menyelesaikan permasalahan yang dihadapi. Jakarta sebagai kota jasa ini juga ditetapkan sebagai MISI Pemerintah DKI Jakarta. Sebagai kota jasa, Pemda DKI berarti menfokuskan sistem manajemen pemerintahannya sebagai FASILITATOR, yaitu agar dunia usaha dan masyarakat dapat mengoptimalkan potensi sumberdaya-nya. Hal ini juga sesuai dengan semangat reinventing government sebagai paradigma baru dalam manajemen pemerintahan ${ }^{15}$, yang salah satu prinsipnya yaitu sebagai catalyc government. steering rather than rowing. Dalam hal ini, tugas pemerintah lebih difokuskan pada aspek yang stratejik saja, sementara tugas yang lebih teknis operasional diserahkan kepada sektor swasta serta pelibatan partisipasi masyarakat. Dalam upaya merealisasikan misi tersebut, Pemda DKI Jakarta telah mengeluarkan berbagai kebijakan melalui penciptaan iklim usaha yang kondusif (baik untuk menarik investor ataupun pelaku bisnis), membangun infrastruktur jalan, sistem komunikasi berbasis IT, dsb, untuk mempercepat pencapaian mega kegiatan tersebut. Misi ini juga ditunjang oleh VISI Pemda DKI Jakarta yaitu: Jakarta mensejajarkan diri dengan kota-kota besar lain di dunia, yang dihuni oleh masyarakatnya yang sejahtera. Visi Pemerintah DKI Jakartamengandung makna, bahwa Jakarta: (1) siap memasuki persaingan global, dengan kota-kota besar lain di dunia; dan (2) Jakarta akan membangun dirinya sebagai kota metropolitan, dan secara simultan juga secara terus menerus memberikan perhatiannya yang besar pada peningkatan taraf hidup dan kesejahteraan warganya. ${ }^{16}$

Untuk mewujudkan keinginan tersebut, berbagai tantangan dan hambatan dihadapi oleh Pemda DKI Jakarta, baik yang datangnya dari

\footnotetext{
${ }^{15}$ Lihat tulisan David Osborne dan Ted Gaebler: Reinveting Government; How the Entrepreneurial Spirit is 16 Transforming the Public Sector, A Plume Book, USA, 1992. http://bappedajakarta.go.id/download/propeda/Propeda_ BAB3.pdf.
}

lingkungan internal maupun lingkungan eksternal. Tantangan dan hambatan dari lingkungan internal muncul sebagai konsekuensi dari kegiatan pembangunan, beserta dampak yang ditimbulkan, baik berupa dampak positif maupun dampak negatif. Sementara itu, tekanan lingkungan eksternal utamanya disebabkan oleh perkembangan Ilmu Pengetahuan dan Teknologi, seperti; semakin mudahnya masyarakat mengakses informasi global dengan teknologi IT yang semakin murah, serta liberalisasi dalam kegiatan usaha (bisnis) dan investasi. Kesemuanya ini bermuara menjadi suatu perubahan terhadap lingkungan stratejik yang cepat dan tidak terduga dalam proses pertumbuhan kota Jakarta. Hal ini tentunya merupakan informasi penting sebagai dasar bagi penyusunan kebijakan (rencana stratjik) Pemda DKI Jakarta.

\section{Gambaran Kebijakan Pemda DKI Jakarta}

Secara normatif Pemda DKI Jakarta telah menyusun rencana stratejik lima tahunan untuk melakukan berbagai terobosan dalam menyelesaikan berbagai persoalan yang dihadapi, dengan menfokuskan pada berbagai persoalan strategis. Strategi pembangunan Propinsi DKI Jakarta disusun dan disesuaikan dengan setiap bidang di dalam Propeda Propinsi DKI Jakarta yang memiliki 8 bidang pembangunan yaitu: (1) Hukum, Ketentraman Ketertiban Umum dan Kesatuan Bangsa; (2) Pemerintahan; (3) Ekonomi; (4) Pendidikan dan Kesehatan; (5) Kependudukan dan Ketenagakerjaan; (6) Sosial dan Budaya; (7) Sumber Daya Alam dan Lingkungan Hidup; dan (8) Sarana dan Prasarana Kota (http://bappedajakarta.go.id/download/propeda /Propeda_BAB3.pdf)

Skenario kebijakan yang dikembangkan Pemda DKI Jakarta dalam rangka mengimplementasikan ke 8 (delapan) bidang kegiatan pembangunan dimaksud, dilakukan secara terencana melalui program REGOM (Reinventing Government), tentunya dengan tetap memperhatikan visi, misi, tujuan dan sasaran yang tertuang dalam renstra Pemda DKI Jakarta. Program REGOM dimaksud adalah suatu kebijakan Pemda DKI Jakarta dalam melakukan perubahan dan pembaharuan manajemen pemerintahan. Fokus perubahan 
dan pembarahuan manajemen pemerintahan, yaitu:

1. Reformasi Anggaran (Perubahan anggaran berbasis kinerja)

2. Revitalisasi Organisasi

3. Kemitraan dan privatisasi.

\section{Perubahan anggaranberbasis kinerja(reformasi anggaran)}

Efesiensi dan efektivitas penyelengaraan tugas-tugas umum pemerintahan dan pembangunan sangat ditentukan oleh kinerja anggaran (budgeting performance). Karena itu anggaran merupakan salah satu ukuran dalam menentukan kinerja sistem pemerintahan, mengingat anggaran merupakan bagian integral dari perencanaan program.

Dalam reformasi anggaran, paradigma masa lalu yaitu spending (menyerap anggaran sehingga tidak terjadi sisa anggaran pembangunan/SIAP) dirubah menjadi earning.
Artinya, birokrasi DKI Jakarta saat ini dutuntut juga untuk melakukan income generating untuk membiayai kegiatan birokrasi pemerintahannya. Sehingga kinerja keuangan dilihat sekarang ini selain kemampuan menyerap anggaran ke dalam program yang berkualitas, juga dilihat dari kemampuan Pemda dalam memperoleh dana (earning capacity). Untuk itu dilakukan reorientasi penataan fungsi unit-unit kerja dari perspektif anggaran. Reorientasi fungsi unitunit kerja di lingkungan Pemda DKI Jakarta tersebut, kemudian dikelompokkan ke dalam 3 tipe anggaran:

1. Unit kerja yang tugasnya mengumpulkan pendapatan (revenue center);

2. Unit kerja yang tugasnya lebih banyak memberikan jasa pelayanan publik kepada masyarakat umum (cost center/public service);

3. Unit kerja yang tugasnya memberi layanan kepada masyarakat dan memungut retribusi atas layanan yang diberikan (mix center)

Tabel 1. Contoh dari unit kerja pada masing-masing tipe antara lain:

\begin{tabular}{lll}
\hline \multicolumn{1}{c}{ Revenue Centre } & Cost Centre/Public Service & \multicolumn{1}{c}{ Mix Centre } \\
\hline Dinas Pendapatan & Dinas Sosial & Dinas LLAJ \\
\hline Perusahaan Daerah & Dinas Kependudukan & Dinas Kebersihan \\
\hline Badan Usaha Milik Daerah & Dinas Kebakaran & Dinas Tata Kota \\
\cline { 2 - 2 } Lainnya & Dinas Pertamanan & \\
\cline { 2 - 3 } & Badan Kepegawaian & \\
\cline { 2 - 3 } & Bawasda &
\end{tabular}

Sumber: Hasil analisis terhadap Tupoksi dan renstra OPD di lingkungan DKI

\section{Revitalisasi Organisasi}

Tugas umum pemerintah adalah fungsi mengatur, mengarahkan, membina, mendorong, mengawasi, mengendalikan, mengayomi. Merevitalisasi organisasi pemerintahan, dengan demikian, mutlak diperlukan agar setiap sistem yang dibangun dapat bekerja secara optimal menjawab tantangan yang dihadapi.

Keberhasilan suatu organisasi yang besar dan kompleks (seperti birokrasi Pemda DKI Jakarta) dalam melaksanakan visi dan misinya, sangat ditentukan oleh kepekaan dan kemampuan mengidentifikasi perubahan lingkungan strategisnya. Perubahan lingkungan begitu cepat dan terkadang tidak terduga menuntut kemampuan suatu organisasi beradaptasi dengan lingkungannya. Dengan demikian, untuk membangun kepekaan organisasi dalam merespons dinamika perubahan lingkungan, dituntut untuk melakukan penataan dan pembangunan organisasi pemerintahan secara terus menerus dan berkelanjutan. Penataan dan pembangunan aspek-aspek penting dalam organisasi dimaksud meliputi, (1) aspek regulasi; (2) aspek budaya kerja; (3) aspek sistem dan prosedur kerja (SOP), serta (4) sistem informasi manajemen yang berbasis IT dalam rangka mewujudkan $e$ government.

Sementara itu, faktor lainnya yang utama dan terutama dari organisasi pemerintahan adalah faktor sumberdaya aparatur pemerintah. Pengembangan SDM aparatur ini pada dasarnya ditujukan untuk membentuk sosok aparat pemerintah yang professional dalam 
melaksanakan tugas-tugas umum pemerintahan dan pembangunan. Adapun aspek-aspek penting dalam membentuk sosok SDM aparat yang professional, yaitu: (1) membangun SDM aparatur yang inovatif; (2) membangun kecerdasan intelektual, mental dan spiritual (intelectual, emotional dan spiritual quation); (3) melakukan pembinaan disiplin kerja; (4) memiliki keterampilan teknis yang sesuai bidang tugasnya; (5) memiliki jiwa kepemimpinan sebagai pelayan publik; (6) serta kesehatan jasmani dan rohani yang mendukung pelaksanaan tugas publik yang bebannya berat. Pembangunan terhadap keseluruhan aspek tersebut diselenggarakan dengan menggunakan manajemen sumberdaya manusia, mulai dari perencanaan SDM pegawai, pengembangan fungsi-fungsi SDM, utamanya dalam hal human resource development, serta sistem imbalan yang kompetitif, yang kesemuanya itu dilakukan sebagai upaya untuk merespons tuntutan dan tekanan perubahan lingkungan stratejik.

\section{Privatisasi dan Kemitraan}

Upaya mengikutsertakan peran serta swasta dalam pelaksanaan tugas-tugas umum pemerintahan, khsusunya pelayanan publik dan pembangunan, sejalan dengan pendapat ahli dari berbagai kalangan, akademisi, politikus, dan birokrat bahwa swastanisasi secara ideologis adalah salah satu cara terbaik dalam menunjang ekonomi pasar, dan untuk mengurangi defisit anggaran pemerintah.

Maksud dan tujuan pelibatan peran serta swasta dan masyarakat dalam pembangunan serta pelayanan publik adalah :

1. Membantu mengatasi keterbatasan pemerintah dalam penyediaan sarana dan prasarana kota (peran pemerintah bersifat steering, sementara peran masyarakat dan dunia usaha bersifat rowing);

2. Menyediakan layanan publik bagi masyarakat DKI secara lebih efesien dan efektif (faster, better, cheaper, newer);

3. Mencari model-model peran serta (kemitraan) masyarakat dan dunia usaha, agar dapat mengatasi persoalan beban biaya dan resiko kepada pihak non pemerintah (sektor swasta) melalui prinsip kerjasama yang saling menguntungkan bagi pemerintah, pihak swasta, dan civil society,
4. Memberikan kesempatan kepada pihak swasta untuk tumbuh dan memiliki daya saing yang tinggi. Melalui kemitraan dengan pemerintah diharapkan dapat meningkatkan keahlian dan profesionalisme pihak swasta untuk ikut terlibat dalam sektor publik, dengan mendapatkan penghasilan sesuai dengan manfaat yang dihasilkan.

5. Menumbuhkan kesadaran masyarakat untuk memelihara lingkungannya, utamanya memelihara sarana publik agar terjaga dan berfungsi dengan baik.

\section{Analisis terhadap Skenario Eksisting}

Penerapan kebijakan REGOM (reinventing gorvernment) dalam manajemen Pemda DKI Jakarta sesungguhnya sudah menerapkan sistem manajemen pemerintahan modern. Ide reinventing government muncul sebagai kritik terhadap birokrasi model Weber yang dianggap sudah usang, karena tidak mampu menjawab persoalan pemerintahan saat ini. Pada akhir abad ke XIX, model birokrasi memperlihatkan keampuhannya sebagai organisasi yang rasional dan efesien di dalam menggantikan pelaksanaan kekuasaan yang sewenang-wenang oleh rejim otoriter (masa depresi). Model birokrasi berjalan untuk jangka waktu yang lama, bukan karena efesien, tapi karena dapat menciptakan stabilitas yang sangat diperlukan setelah masa depresi. Menjelang akhir abad ke XX, birokrasi dirasakan lambat, tidak efesien dan impersonal. Hal ini dapat dipahami karena tuntutan rakyat terhadap public service semakin meningkat, sementara kemampuan pemerintah semakin terbatas. Diperlukan suatu pemerintahan memberi wewenang lebih banyak kepada warga negara ketimbang melayani mereka. Sehingga perlu dipikirkan kembali cara untuk menata ulang manajemen pemerintahan (reinventing government).

Diperlukan suatu visi dan framework yang baru di dalam menata ulang pemerintahan dengan memberi penekanan pada bagaimana entrepreneurial government berkerja/beroperasi. Konsep kewirausahaan (entrepreneurship) merupakan kata kunci dalam tulisan Osborne dan Gaebler. Namun penerapan konsep kewirausahaan dalam institusi pemerintah seringkali menimbulkan pro 
dan kontra. Kewirausahaan yang berkembang pesat pada perusahaan swasta yang berorientasi mencari keuntungan, serta keberanian dalam mengambil resiko, dikhawatirkan dalam merusak rasa keadilan. Kewirausahaan dalam konteks tulisan ini lebih berkonotasi pada kreativitas, inovasi, berdaya saing tinggi, kemampuan mancari peluang. Jadi, kewirausahaan bukan hanya milik swasta, karena bisa saja terjadi wirausahawan pada perusahaan swasta berubah menjadi birokrat, apabila organisasinya disusun untuk mendorong perilaku birokratis.

Namun, pemerintahan tidak dapat dijalankan seperti halnya perusahaan bisnis, karena adanya prinsip authority dan accountability, sebagai menifestasi dari pelakasanaan demokrasi dari rakyat. Artinya setiap pengambilan keputusan harus bersifat demokratis dan terbuka, karena itu ia bergerak lambat ketimbang perusahaan bisnis yang para manajernya dapat mengambil keputusan dalam ruang yang tertutup. Perbedaan mendasar lainnya antara pemerintahan dan bisnis adalah:

- Pimpinan bisnis didorong oleh motif laba, pimpinan pemerin-tahan didorong oleh keinginan untuk bisa dipilih kembali.

- Perusahaan bisnis memperoleh sebagian besar uang dari pelanggannya, sedangkan pemerintah dari pembayar pajak.

- Perusahaan biasanya didorong oleh kompetisi, sedangkan pemerintah biasanya menggunakan monopoli.

Dalam pemeritahan model birokrasi Weber bahwa umumnya hanya ada dua jalan keluar dari krisis umum yang berulang, yaitu; menaikan pajak, atau mengurangi pengeluaran. Ide reinventing government merupakan pilihan ketiga di dalam menata ulang suatu pemerintahan yang lebih baik. Osborne dan Gaebler (1992) mengusulkan 10 prinsip untuk melakukan reinventing government, yaitu:

- Catalytic Government: Steering Rather Than Rowing.

- Community-Owned Government: Empowering Rather than Serving

- Competitive Government: Injecting Competition into Service Delevery.

- Mission Driven Rather Than Rule Driven.

- $\quad$ Result Oriented Government: Funding Outcomes, Not Inputs.
- $\quad$ Customer Driven Government: Meeting the Needs of the Customer, Not the Bureaucracy.

- Enterprising Government: Earning Rather than Spending.

- Anticipatory Government: Prevention Rhather Than Cure.

- Decentralized Government: From Hierarchy to Participation and Team Work.

- Market Oriented Government: Leveraging Change Through the Market.

Pemikiran ini juga sejalan dengan era good governance. Era ini sebagai koreksi dari keterbatasan atas pendekatan government centris dengan kebijakan sentralistik-nya. Dalam pendekatan good governance pola yang digunakan adalah bahwa penyelenggaraan pelayanan publik dan pembangunan akan lebih efektif dan efesien apabila bersifat multistakeholders, yang melibatkan peran secara sinergis antara pemerintah (clean professional government), dunia usaha (good corporate governance), dan masyarakat madani (civil society).

Dengan demikian, reformasi anggaran, reformasi organisasi, dan privatisasi perlu dilihat dari perspektif good governance. Dengan demikian ke-3 bentuk reform tersebut sesungguhnya saling terkait dalam satu paket. Misalnya, reformasi anggaran, sesungguhnya juga mengundang peran serta masyarakat dan dunia usaha untuk ikut membiayai kegiatan pelayanan publik.

Program Pemberdayaan Masyarakat Keluharan (PPMK), misalnya, merupakan sistem pembangunan kelurahan di DKI yang melibatkan partisipasi masyarakat dan dunia usaha di dalam melaksanakan aspek fisik sarana dan prasarana dasar (seperti; pembangunan jalan, tempat ibadah, posko keamanan masyarakat), dan bahkan bantuan modal bagi usaha kecil melalui bantuan dana bergulir (revolving fund). Artinya, reformasi anggaran juga sesungguhnya sudah merupakan upaya menuju kearah paritisipasi dan kemitraan antara pemerintah dengan dunia usaha dan masyarakat. 


\section{SIMPULAN}

Berdasarkan hasil pembahasan terdahulu, maka dapat ditarik kesimpulan bahwa pendekatan organisasi sebagai sistem terbuka sangat relevan untuk mengkaji organisasi Pemda DKI, dengan mencoba memahami lingkungan eksternal yang mempengaruhinya, baik berupa tantangan maupun peluang, sebagai bahan informasi bagi penyusunan kebijakan (rencana stratejik) ke depan. Tantangan yang dihadapi Pemda DKI, dalam posisinya sebagai ibukota dapat diidentifikasi dari lingkungan internal (skala lokal) dan lingkungan eksternal (skala nasional/internasional). Pada skala lokal persoalan kependudukan, ketenagakerjaan, kemiskinan, transportasi/ perparkiran, dan lingkungan hidup merupakan masalah inti yang memerlukan penanganan secara tepat dan cepat. Pada skala nasional/internasional, persoalan liberalisasi perdagangan merupakan masalah paling krusial.

Skenario Pemda DKI Jakarta untuk menangani tantangan yang dihadapi dengan menggunakan kebijakan REGOM (reinventing government manajemen), yaitu dengan melakukan perubahan dan pembaharuan sistem manajemen pemerintahan. Kebijakan khusus yang dibangun adalah dengan melakukan reformasi anggaran, reformasi organisasi, dan kebijakan privatisasi dan kemitraan dengan dunia usaha (swasta) dan masyarakat.

Kebijakan REGOM ini sudah sesuai dengan paradigna manajemen perintahan baru, yaitu GOOD GOVERNANCE SYSTEM sebagai koreksi dari keterbatasan model masa lalu yang bersifat gorvenment centris. Pendekatan good governance, terjadi sinergis peran antara pemerintah (yang clean and professional government), dunia usaha/swata (good corporate governance) dan masyarakat madani (civil society).

\section{DAFTAR PUSTAKA}

Charles, Perrow. 1967. A Framework for the Comparative Analysis of Organizations, American Sociological Review, p 194-208.
David Osborne dan Ted Gaebler. 1992 Reinveting Government; How the Entrepreneurial Spirit is Transforming the Public Sector, A Plume Book, USA.

Edwin Gerloff. 1985. Organizational Theory and Design; A Strategic Approach for Management, Mc. Graw Hill.

James D. Thompson. 1967. Organization in Action, New York; Mc Graw Hill, 1967.

Joan Woodward. 1965. Industrial Organization, Theory and Practice, London Oxford University Press.

Jeffrey Pfeffer. 1982. Organizations and Organization Theory, London, Pitman Publishing Inc.

Karl E. Weick. 1976. The Social Psychology of Organizing, Reading Addison Wesley.

Michael T. Hannan and John H. Freeman, The Population Ecology of Organization, American Journal of Sociology,vol 82, p 929-964.

Paul R. Lawrence and Jay W. Lorsch. 1967 Organization and Environment, Boston Graduate School of Business Administration, Harvard University 1967, p 25-30.

Peter Berger and Thomas Luckman. 1981. The Social Construction of Reality, England, Penguin Books Ltd.

Roy A Rapaport. 1971. Ritual, Sanctity, and Cybernetics, American Anthropologist, Vol 73.

Richard M. Cyert and James G. March. 1963. A Behavioral Theory of the Firms, Englewood Cliffs, N.J. Prentice Hall

S.B. Hari Lubis dan Martani Huseini. 1988. Teori Organisasi: Suatu Pendekatan Makro, Pusat Antar Universitas-IImu Sosial-Universitas Indonesia, 1988.

Perubahan dan Pembaharuan Memacu Kinerja Pemerintahan Kota; Study Kasus 
Pemerintah DKI Jakarta, Tim Perubahan dan Pembaharuan Manajemen Pemerintah DKI Jakrta, 1997.

Tom Burn dan G.M. Stalker. 1961. The Managament of Innovation, Tavistock, 1961.
W. Graham Astley and Andrew Van de Ven. 1983. Central perspectives and Debates in Organization Theory, Administrative Science Querterly, 28, 1983, p 248-250.

\section{Website:}

http://bappedajakarta.go.id/download/propeda/ Propeda_BAB3.pdf 